\title{
Microscopy and Morphometry of Integument of the Foot of Pulmonate Gastropods Arion rufus and Helix pomatia
}

\author{
Z. TONAR ${ }^{1}$, A. MARKOŠ ${ }^{2}$ \\ ${ }^{1}$ Department of Histology and Embryology, Faculty of Medicine in Pilsen, Charles University in Prague \\ ${ }^{2}$ Department of Philosophy and History of Science, Faculty of Sciences, Charles University in Prague, \\ Czech Republic \\ Received October 16, 2003 \\ Accepted February 11, 2004 \\ Abstract \\ Tonar Z., A. Markoš: Microscopy and Morphometry of Integument of the Foot of Pulmonate \\ Gastropods Arion rufus and Helix pomatia. Acta Vet. Brno 2004, 73: 3-8. \\ The aim of our work was to carry out morphometric analysis of histological sections through the \\ foot of pulmonate gastropods with an output suitable as a data entry for its biomechanical scale- \\ dependent modelling. \\ We studied serial histological sections of two samples of ventral surface of the foot of Helix \\ pomatia and Arion rufus. The structure of smooth muscle cells was examined by transmission \\ electron microscopy. The relative proportions of cardinal tissue constituents was calculated from \\ the area of colour photomicrographs with constant magnification. \\ Because of ventro-dorsal morphological anisotropy, the ventral foot was divided into two \\ layers parallel with the body surface. These layers, though delimited arbitrarily, were \\ morphologically well distinguished and presumably of diverse biomechanical properties. The \\ relative area proportions in sections through the superficial/deep subepithelial layer of \\ integument (mean percentage values $\pm \mathrm{SD}, \mathrm{n}=30$ ) were as follows: $H$. pomatia $38 \pm 2.5 / 22 \pm 1.5$ \\ of smooth muscle cells, $51 \pm 3.4 / 28 \pm 1.8$ of collagen connective tissue, and $9 \pm 0.6 / 48 \pm 3.6$ of \\ haemocoelic sinuses. In $A$. rufus, the corresponding values were $31 \pm 2.1 / 24 \pm 1.6,50 \pm 3.3 / 36$ \\ \pm 2.4 , and $17 \pm 1.1 / 26 \pm 1.1$, respectively. In $H$. pomatia, the maximal length of smooth muscle \\ cells was $218 \mu \mathrm{m}$, the maximal transverse diameter of muscle cells was $6.1 \mu \mathrm{m}$, and the maximal \\ depth of mucus glands in subepidermal layer was $462 \mu \mathrm{m}$. In A. rufus, the values were $220 \mu \mathrm{m}$, \\ $6.0 \mu \mathrm{m}$, and $266 \mu \mathrm{m}$. \\ The data described neither in/homogenity, nor directional distribution and anisotropy of the \\ tissue constituents. The results can be used as qualified input parameters for a simplified \\ biomechanical model of the gastropod integument.
}

Gastropoda, ventral integument of the foot, morphometric analysis, biomechanical model

Scale dependent modelling, taking into account the structure of matter at both macroscopic and microscopic scales (Holeček and Krákora 2001; Holeček et al. 2003), belongs to progressive methods in biomechanics of soft tissues. Recently, the foot of pulmonate mollusc was suggested to be a suitable structure for using this approach in modelling of smooth muscle cells (SMC) and connective tissue because the tissue sample of a poikilothermic organism is supposed to have several advantages concerning the experimental identification of its mechanical parameters. Because of its relatively low metabolic rate, it should be possible to perform an in vitro dynamic-mechanical analysis of the tissue to gain results comparable to in vivo conditions. Such data are usually very hard to obtain in tissue samples of homoiothermic organism.

The composition and properties of contractile apparatus, other parts of cytoskeleton and collagen fibrils of Helix pomatia has been subject of biochemical and evolutionary comparative studies (Schmut et al. 1990; Geisler et al. 1998; Greenberg et al. 1997). Interpretation of the biomechanical experiments implies correlation with histological data

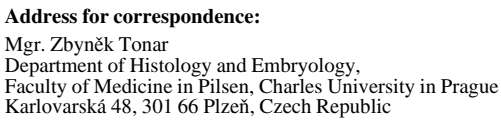

Phone: +420377593320

Fax: +420 377593329

E-mail:tonar@ lfp.cuni.cz 
concerning constituents of the tissue sample. The overall microstructure of gastropod integument was reviewed by Luchtel and Deyrup-Olsen (2001). Bairati and Comazzi (2001) gave comprehensive description of the ultrastructure of the subepidermal connective tissue in different zones of mollusc integument. Kier (1988) reported on the spatial arrangement of the smooth muscle and the hydrostatic function of haemocoelic cavities. Tompa and Watabe (1976) investigated the muscle attachment to the gastropod shell. Nevertheless, none of these papers brought quantitative results.

The aim of our work was to carry out elementary morphometric analysis of the histological sections through the foot of selected pulmonate gastropods, with an output suitable as a data entry for its biomechanical modelling.

\section{Materials and Methods}

Samples were taken from the ventral surface of the foot of terrestrial snail Helix pomatia and terrestrial slug Arion rufus, both caught in Pilsen in July 2003. First we fixed the tissue blocks of $10 \times 10 \times 5 \mathrm{~mm}$ in $10 \%$ buffered formalin and processed them by common paraffin technique. Each sample was cut into 30 serial sections (thickness of $5 \mu \mathrm{m}$ ) with transversally oriented cutting plane, and stained with hematoxylin and eosin (HE), Mallory trichrome, green trichrome modified according to Kočová (1970), PAS reaction and alcian blue method. We fixed another six tissue blocks of $1 \times 1 \times 1 \mathrm{~mm}$ (originating from $\mathrm{H}$. pomatia only) in $6 \%$ glutaraldehyde, post-fixed in $1 \%$ osmium tetroxide, and embedded in EPON 812. Semi-thin sections ( $1 \mu \mathrm{m}$ thick) were stained with $1 \%$ toluidin blue. Ultrathin sections were contrasted with uranyl acetate and examined in transmission electron microscope (TEM) Tesla BS 500. For description of various cell types and structures encountered in gastropod integument, we followed the well documented terminology of Luchtel and Deyrup-Olsen (2001) and Pedersen (1991).

We assessed the relative proportions of the SMC, collagen fibres and haemocoelic spaces in the area of 30 histological sections through the integument of both species. The tissue components were identified due to their relevance to intervals of red-green-blue (RGB) values or due to RGB gradient (with variable tolerance), using the software Area (Sofo Brno, Czech Republic). The whole section area of the photomicrographs $(3072 \times 2035$ pixels, 24 bit colour depth) was equal to $100 \%$. We calculated a mean \pm SD of individual values from 30 sections. The constant magnification was chosen so that the photographed area could be large enough to avoid local tissue heterogeneities. The preliminary examination showed considerable ventro-dorsal morphological anisotropy of the tissue samples, therefore we divided the ventral foot of the animals into two layers (superficial and deep one) parallel with the body surface. Although the boundaries between the neighbouring layers were arbitrary, they were well morphologically defined and easy to be found. In the future they may appear to have different biomechanical properties, therefore the results are presented for each of them separately.

Next we performed linear morphometry in the same calibrated micrographs by using the ImageJ software (Wayne Rasband, National Institute of Health, Bethesda, Maryland, USA). The parameters measured were (1) depth of the ventral body wall occupied by mucous glands; (2) length and (3) transverse diameter of SMC present in the animal's foot.

\section{Results}

\section{Helix pomatia}

The body surface was covered with a single-layered columnar epithelium equipped with both cilia and microvilli (the latter confirmed also with electron microscopy). Large mucus-secreting and mucus-storing cells extended deep into the subepithelial matrix (Plate I, Fig. 1), surrounded by individual SMC and connective tissue. The intra- and extracellular mucus was negative in PAS method, but it stained with alcian blue, and showed beta-metachromasia in semi-thin toluidine sections (Fig. 2). Scarce channel cells also penetrated the epithelium, stained homogeneously in semi-thin sections. The subepidermal connective tissue was traversed by processes of gland cells. Some of the subepithelial SMC nearly contacted the basement membrane of epidermis. Other minor cell types were found, as fibroblasts, nerve cells, elongated or branched rhogocytes with electron-dense granules, pigment cells (more numerous towards the epithelial surface), and amoebocytes. The superficial subepithelial layer consisted of epithelium, mucous glands, smooth muscle and dense connective tissue (Plate II, Fig. 3). In the deeper layer, 
the muscle and connective tissue was interwoven by numerous capillary processes of haemocoelic sinuses (Fig. 4).

Smooth muscle cells, surrounded by collagen fibrils in the subepithelial stratum of integument, were the principal structures of our interest. The SMC were dispersed beneath the epithelium, either individually or as bands and columns of longitudinal, transverse, or radial orientation with respect to the major body axis. The SMC were spindle-shaped and uninucleate, with their nuclei lying in peripheral cytoplasm. Within the cells, thin (actin) and thick (myosin) filaments intermingled in arrays without any apparent pattern. Numerous elliptical dense bodies could be recognized among the myofilaments. Similar electron-dense plaques occurred in the cell membranes (Plate III, Fig. 5). Besides mitochondria and glycogen stores, invaginations in the cell membrane were recognisable as distinct structures, either as tubules lined with basal lamina or as simple caveolae. Each individual SMC was surrounded by basal lamina, connected directly to collagen fibrils, the latest formed an irregular meshwork whose density varied according to the zone of integument.

\section{Arion rufus}

The qualitative description of the samples given in $H$. pomatia was found to be valid also in A. rufus (Fig. 6). Quantitative differences are presented in Fig. 7 and in Table 1.

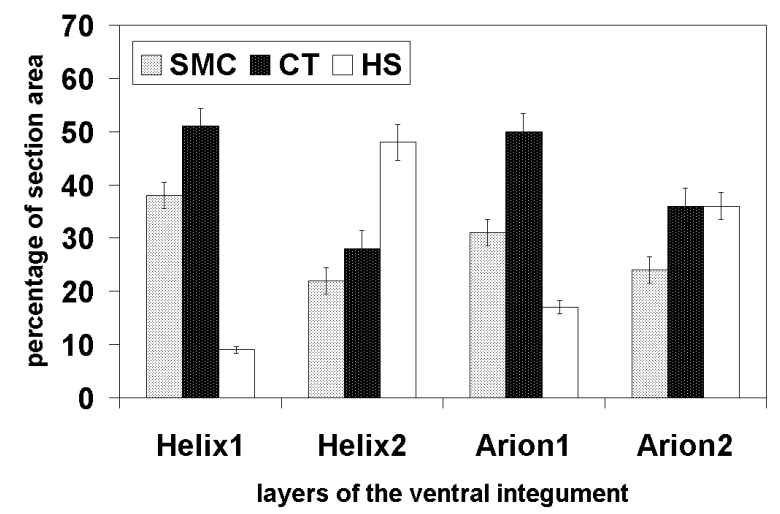

Fig. 7. Relative proportions of the SMC, connective tissue (CT) and haemocoelic sinuses (HS) in the area of histological sections through superficial (indexed as 1) and deep (indexed as 2) layer of integument in Helix pomatia and Arion rufus (mean $\pm \mathrm{SD}, \mathrm{n}=30$ ).

\section{Morphometry}

The relative proportions of the SMC, collagen fibres and haemocoelic spaces are summarized in Fig. 7. Table 1 presents maximal longitudinal and transversal diameters of SMC and maximal depth of mucus glands in subepidermal layer.

Table 1

Maximal length (SMC-ML), maximal transverse diameter (SMC-MD), and maximal depth of mucus glands (MG) measured in calibrated photomicrographs of 30 histological sections through foot integument in Helix pomatia and Arion rufus.

\begin{tabular}{|lrrr|}
\hline & SMC-ML $[\mu \mathrm{m}]$ & SMC-MD $[\mu \mathrm{m}]$ & MG $[\mu \mathrm{m}]$ \\
\hline H. pomatia & 218 & 6.1 & 462 \\
\hline A. rufus & 220 & 6.0 & 266 \\
\hline
\end{tabular}




\section{Discussion}

The input for the image area analysis required micrographs with high colour contrast. This demand was met by overall trichrome staining, differentiating the SMC and collagen sufficiently in most cases. Still the selection of some pixels remained subjective during the analysis, thus the source image had to be reviewed repeatedly. This made the procedure unsuitable for an automatized routine. The category "connective tissue" seemed to yield the most questionable results because in some cases it was impossible to differentiate between the peripheral cytoplasm of SMC and connective tissue elements. The main component of connective tissue was collagen, well stained by trichrome methods. Other extracellular matrix substances, such as glycoproteins, proteoglycans, and glycosaminoglycans, stained poorly. Nevertheless, due to the thickness of the sections and the magnification used, they were mostly masked by overlapping collagen and thus fell into the appropriate category. While the organization of dorsal mantle zone differs among the gastropods, depending on the presence and form of the shell (Bairati and Comazzi 2001), we found the ventral integuments to be very similar in Arion and Helix, both in appearance and quantitatively.

According to Cavalieri-Acker principle (Russ and Dehoff 2001), the area fractions of the tissue constituents may be identified with their volume fractions. Tissue isotropy and sufficient number of random oriented sections are the necessary conditions for this. In the case of anisotropy, more sophisticated stereological methods and an appropriate orientation of tissue sections should be used and the orientation of the tissue components must be known beforehand. Since our study has not fulfilled isotropy requirements in all segments of the tissue, the results summarized in Fig. 7 can not be considered as matching also volume fractions.

On the other hand, due to precise calibration the results of linear morphometry (Table 1) can be considered as accurate, correct and reproducible. The maximal depth of the supepidermal tissue traversed by mucous cells was measured because the vast deposits of mucus modify the mechanical properties of the superficial layer. This fact will undoubtedly play its role in interpretation of the forthcoming mechanical experiments. As to SMC length, only the maximal value is shown. It was hardly possible to intersect the full length of an individual slightly curved and spindle-shaped SMC by a longitudinal section plane. Therefore, the identification of cell margin was ambiguous and most of the length values appeared to be shorter than the real dimensions. On the contrary, the measurement of transverse diameter of SMC posed no serious hindrances.

Rogers (1969) reports in H. aspersa that the number of muscle bundles increases towards the epithelial surface of the foot. We confirmed it in the superficial layer only. In the same paper, the SMC is reported to be about $30 \mu \mathrm{m}$ long and $3 \mu \mathrm{m}$ thick. Although measured in different species, we find no explanation for the discrepancy between the Rogers' results and ours.

For a long time, it was not clear to what extent the properties of gastropod SMC can be compared or even identified with those of mammals. Greven (1978) analyzed viscoelastic and plastic properties of the retractor pedis smooth muscle in $H$. pomatia, which manifested themselves as creep after constant loading or stress relaxation after constant stretch. His experiments suggested the creep and stress relaxation in snail to be governed by the same principles as in vertebrate SMC (e.g. taenia coli of the guinea pig).

The tubular invaginations which we observed in the SMC were neither so well defined tubules, nor oriented at right angles to the muscle cell plasma membrane, as reported in the SMC of the optic tentacle (Rogers 1968) and penis retractor muscle (Schlote 1963).

Beyond any doubt, the apparently unorganized dense bodies observed in SMC of Helix correspond to the Z-discs in vertebrate muscle (Royuela et al. 1999). They are formed by 
actin-associated proteins, and their role is to anchor actin filaments to other structures, and to modulate their polymerization. The SMC differ from the vertebrate smooth muscle in the abundance and thickness of myosin filaments. Actin filaments in SMC of Helix are not arranged parallel throughout their course. They converge on discontinuously distributed anchorage sites. We did not measure the myofilament length and diameter, these data, however, are available for musculature of $H$. aspersa (Roy u ela et al. 2000). These authors found that SMC of Helix had lower myosin/actin ratio than striated invertebrate muscles, which suggests their contraction strength to be lower. The myofilament length was inversely related to the contraction speed, which was higher in the striated muscle than in SMC. In SMC, the presence of apparently unordered electron-dense bodies instead of ordered Z-lines permits a certain overlapping of thin filaments, which results on an increasing in the range of shortening. Moreover, these authors elaborated useful and convincing criteria for classification of invertebrate muscles according to immunohistochemical evaluation and myofilament parameters, which seem to be crucial for theoretical explanations of biomechanic experiments with those tissues. However, Royuela et al. (2000) did not cite the papers of Schlote (1968) and Rogers (1969), who had published very similar results in both $H$. pomatia and $H$. aspersa.

Data presented in this paper do not show any in/homogenity or directional distribution and anisotropy of tissue constituents. They can be used as qualified input parameters for a simplified biomechanical model of the gastropod integument. In further work, stereological methods should be applied in order to get more information from the image analysis. The question to what extent the muscle contraction is controlled by the central nervous system, peripheral nervous mechanisms, and/or by myogenic mechanisms, should also be clarified. This problem has been studied in retractor penis muscle of $H$. pomatia by Wabnitz (1975), who explained the functional differences between the intact and semiintact preparation. However, the innervation pattern of this muscle considerably differs from that of pedal musculature (Rogers 1969). The present paper gives a quantitative description of normal morphology, which will be used as a reference study for analyses reviewing the range of irreversibility of morphological changes caused by the experiment.

\section{Mikroskopická struktura a morfometrie ventrálního integumentu nohy plžů Arion rufus a Helix pomatia}

Cílem naší práce bylo provést elementární morfometrickou analýzu histologických sérií pedální svalovinou plicnatých plžů, a to formou použitelnou pro datový vstup biomechanického škálového modelu této tkáně. Studovali jsme série histologických řezů dvou vzorků z ventrální stěny nohy hlemýždě Helix pomatia a plzáka Arion rufus. K podrobnějšímu zkoumání morfologie hladkých svalových buněk jsme použili transmisního elektronového mikroskopu. Stanovili jsme poměrné zastoupení klíčových tkáňových složek v ploše barevných mikrofotografií s pevně zvoleným zvětšením.

Morfologie ventrálního integumentu nohy studovaných plžů vykazovala výraznou ventro-dorzální anizotropii. Rozdělili jsme proto popis této tkáně do dvou vrstev rovnoběžných s povrchem těla. Hranice těchto účelově definovaných vrstev byla dobře histologicky definována. Jelikož u obou vrstev předpokládáme odlišné biomechanické vlastnosti, uvádíme výsledky pro každou z nich zvlášt'. Výsledné hodnoty poměrného plošného zastoupení v řezech povrchovou/hlubokou vrstvou subepiteliálního integumentu u $H$. pomatia jsou následující (průměrné procentuální hodnoty $\pm \mathrm{SD}, \mathrm{n}=30$ ): $38 \pm 2,5 / 22 \pm 1,5$ pro hladké svalové buňky, $51 \pm 3,4 / 28 \pm 1,8$ pro kolagenní vazivo a $9 \pm 0,6 / 48 \pm 3,6$ pro hemocoelické sinusy. Odpovídající hodnoty u plzáka $A$. rufus ve stejném pořadí 
tkáňových složek byly $31 \pm 2,1 / 24 \pm 1,6,50 \pm 3,3 / 36 \pm 2,4$ a $17 \pm 1,1 / 26 \pm 1$, 1 . Lineární morfometrie u $H$. pomatialA. rufus ukázala, že maximální délka hladkých svalových buněk byla 218/220 $\mu \mathrm{m}$, jejich maximální př́icný průměr 6.1/6.0 $\mu \mathrm{m}$ a maximální hloubka subepidermální tkáně, do níž zasahovaly hlenové buňky, byla 462/266 $\mu \mathrm{m}$.

Naše údaje nepopisují nehomogenitu struktury, anizotropii, ani směrovou distribuci tkáňových složek. Přesto jsou uvedené kvantifikované morfometrické výsledky připravené $\mathrm{k}$ použití pro kvalifikovaný odhad vstupních parametrů zjednodušeného biomechanického modelu integumentu plžù.

\section{Acknowledgements}

This study was supported by the grant No. 106/02/1357 of the Grant Agency of Czech Republic.

\section{References}

BAIRATI, A, COMAZZI, M 2001: An ultrastructural study of connective tissue in mollusc integument: II. Gastropoda. Tissue and Cell 33: 426-438

GEISLER, N, SCHUNEMANN, J, WEBER, K, HANER, M, AEBI, U 1998: Assembly and architecture of invertebrate cytoplasmic intermediate filaments reconcile features of vertebrate cytoplasmic and nuclear lamintype intermediate filaments. J Mol Biol 282: 601-617

GREENBERG, MJ, DOBLE, KE, LESSER, W, LEE, TD, PENNELL, NA, MORGAN, CG, PRICE, DA 1997: Characterization of myomodulin-related peptides from the pulmonate snail Helix aspersa. Peptides 18: 1099-1106

GREVEN, K 1978: Viscoelastic and plastic properties of visceral smooth muscles in vertebrates. J Biomech 11: 49-55

HOLEČEK, M, KRÁKORA, P 2001: Scale-dependent continuum models in biomechanics. J Mech Eng 52: $175-187$

HOLEČEK, M, ČERVENÁ, O, POIRIER, F 2003: Scale continuum approach in biomechanics: a simple simulation of a microstructural control of tissues' stiffness. Math Comput Simul 61: 583-590

KIER, WM 1988: The arrangement and function of molluscan muscle. In: TRUEMAN, ER, CLARKE, MR (Eds): The Mollusca. Volume 11. Form and Function. Academic Press, London, pp. 211-252

KOČOVÁ, J 1970: Overall staining of connective tissue and the muscular layer of vessels. Fol Morphol 3: 293-295

LUCHTEL, DL, DEYRUP-OLSEN, I 2001: Body wall. Form and function. In: BARKER, GM (Ed): The biology of terrestrial molluscs. CABI Publishing, Wallingford, pp. 147-178

PEDERSEN, KJ 1991: Structure and composition of basement membranes and other basal matrix systems in selected invertebrates. Acta Zool 72: 181-201

ROGERS, DC 1968: Fine structure of smooth muscle and neuromuscular junctions in the optic tentacles of Helix aspersa and Limax flavus. Z Zellforsch 89: 80-94

ROGERS, DC 1969: Fine structure of smooth muscle and neuromuscular junctions in the foot of Helix aspersa. Z Zellforsch Mikrosk Anat 99: 315-335

ROYUELA, M, ASTIER, C, FRAILE, B, PANIAGUA, R 1999: Alpha-actinin in different invertebrate muscle cell types of Drosophila melanogaster, the earthworm Eisenia foetida, and the snail Helix aspersa. J Muscle Res Cell Motil 20: 1-9

ROYUELA, M, FRAILE, B, ARENAS, MI, PANIAGUA, R 2000: Characterization of several invertebrate muscle cell types: a comparison with vertebrate muscles. Microsc Res Tech 48: 107-115

RUSS, JC, DEHOFF, RT 2001: Practical Stereology. 2nd Ed. Plenum Press, New York, 307 p.

SCHLOTE, FW 1963: Neurosekretartige Grana in den peripheren Nerven und in den Nerv-Muskel-Verbindungen von Helix pomatia. Z Zellforsch 60: $325-347$

SCHLOTE, FW 1968: Die dicken Myofilamente der glatten Muskelfasern von Helix pomatia. Z Zellforsch Mikrosk Anat 92: 503-508

SCHMUT, O, ROLL, P, REICH, ME 1990: Biochemical and electronmicroscopic investigations on Helix pomatia collagen. Z Naturforsch 35: 376-379

TOMPA, AS, WATABE, N 1976: Ultrastructural investigation of the mechanism of muscle attachment to the gastropod shell. J Morphol 149: 339-351

WABNITZ, RW 1975: Comparative study of the electrical and mechanical behaviour of an intact, semi-intact and isolated gastropode (Helix pomatia) smooth muscle preparation. Experientia 31: 1167-1170 
Plate I

Tonar Z. and Markoš A.: Microscopy ... pp. 3-8

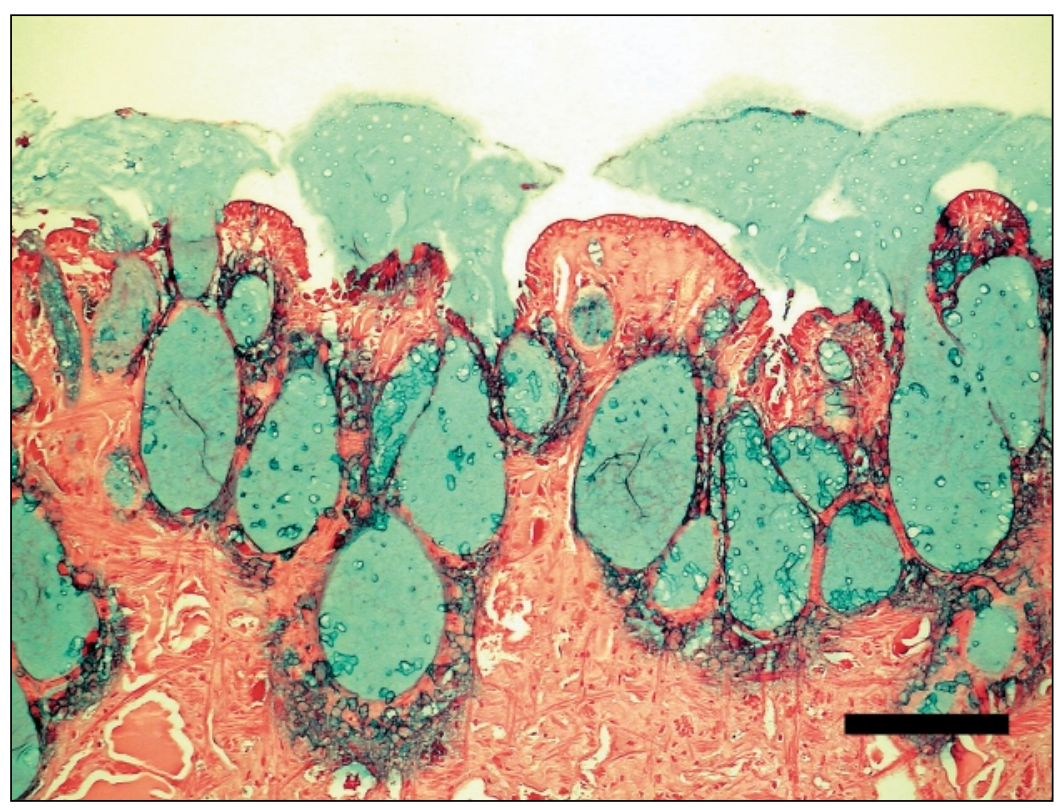

Fig. 1. Mucus-containing cells in the epithelium and subepithelial tissue in ventral integument of Helix pomatia. Alcian blue and nuclear red staining. Bar indicates $100 \mu \mathrm{m}$.

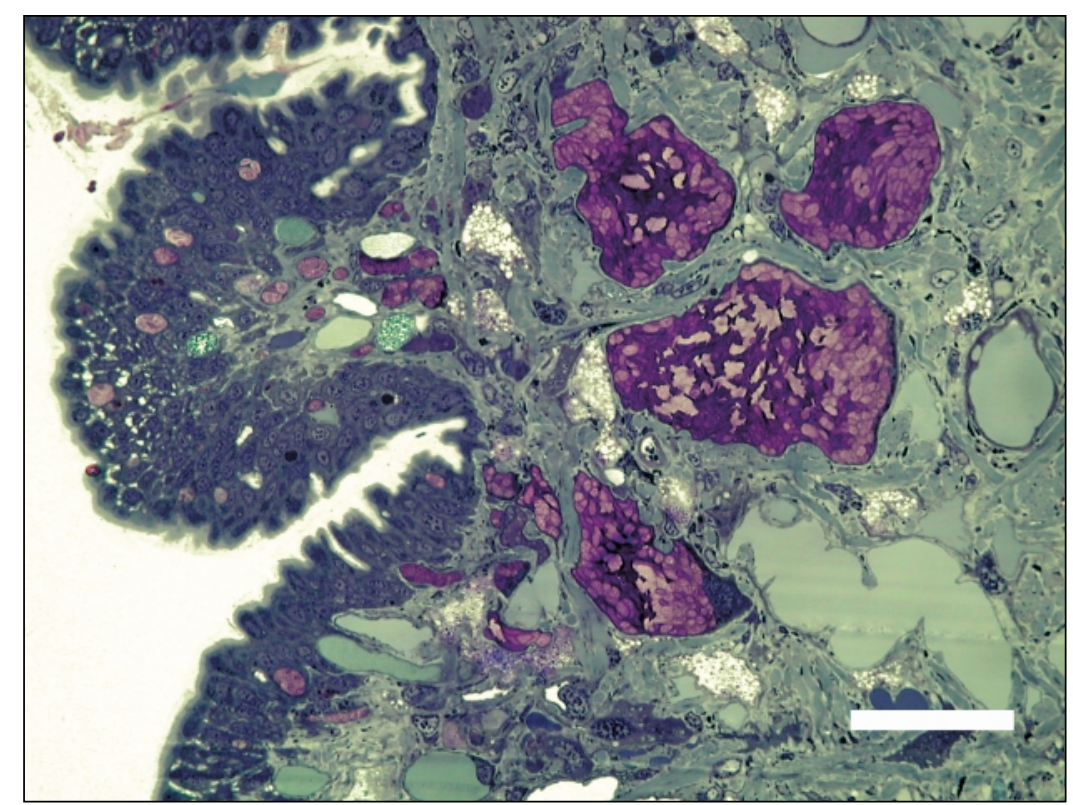

Fig. 2. Microvillous epithelium and subepithelial connective tissue of the ventral integument of Helix pomatia. Beta-metachromatic mucus-containing cells with granular appearance of the mucus. Semi-thin section with toluidin blue staining. Bar indicates $50 \mu \mathrm{m}$. 


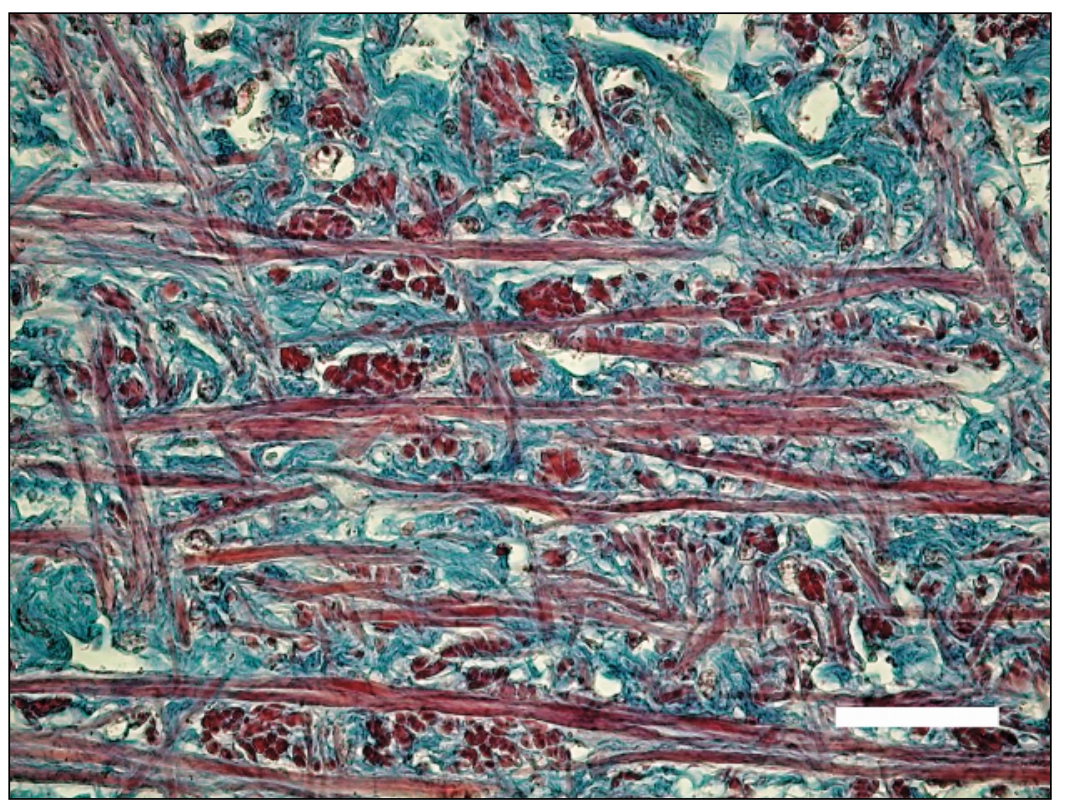

Fig. 3. Subepithelial collagenous connective tissue (blue) of Helix pomatia with three-dimensional meshwork of smooth muscle cell bundles (reddish). Layer Helix1, Mallory's blue trichrome. Bar indicates $50 \mu \mathrm{m}$.

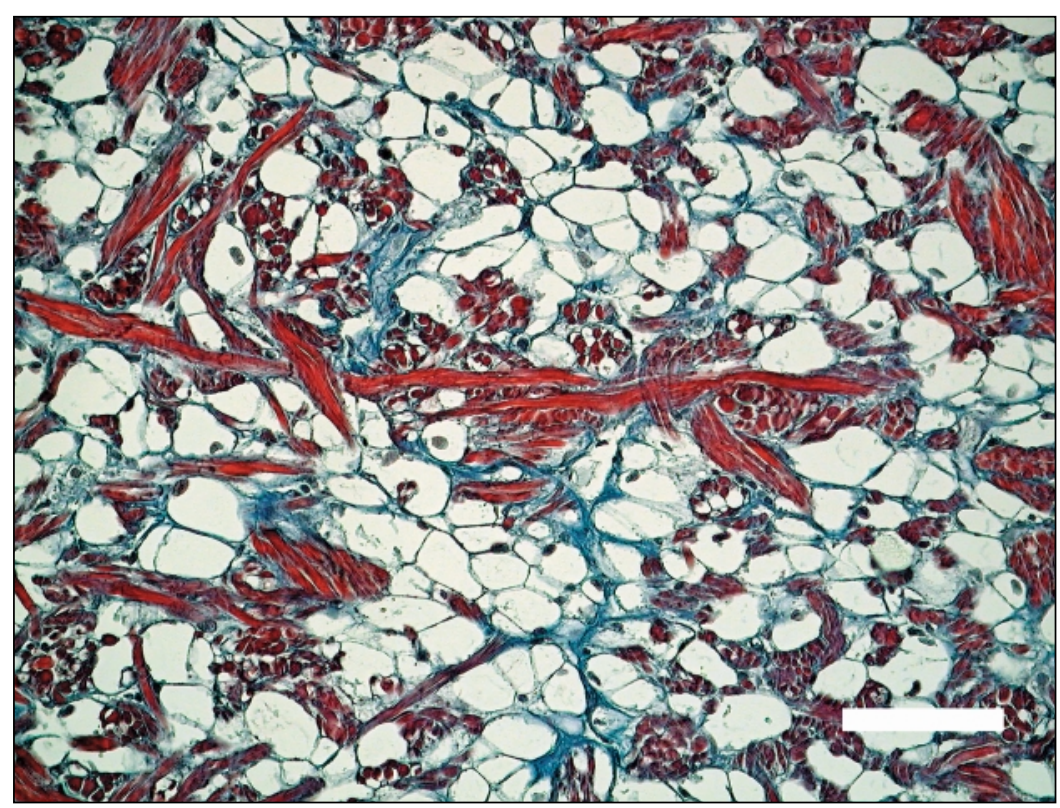

Fig. 4. Deeper layer of pedal integument of Helix pomatia with collagenous connective tissue (blue), system of capillary haemocoelic sinuses (empty spaces), and three-dimensional mesh of smooth muscle cell bundles (reddish). Layer Helix2, Mallory's blue trichrome. Bar indicates $100 \mu \mathrm{m}$. 


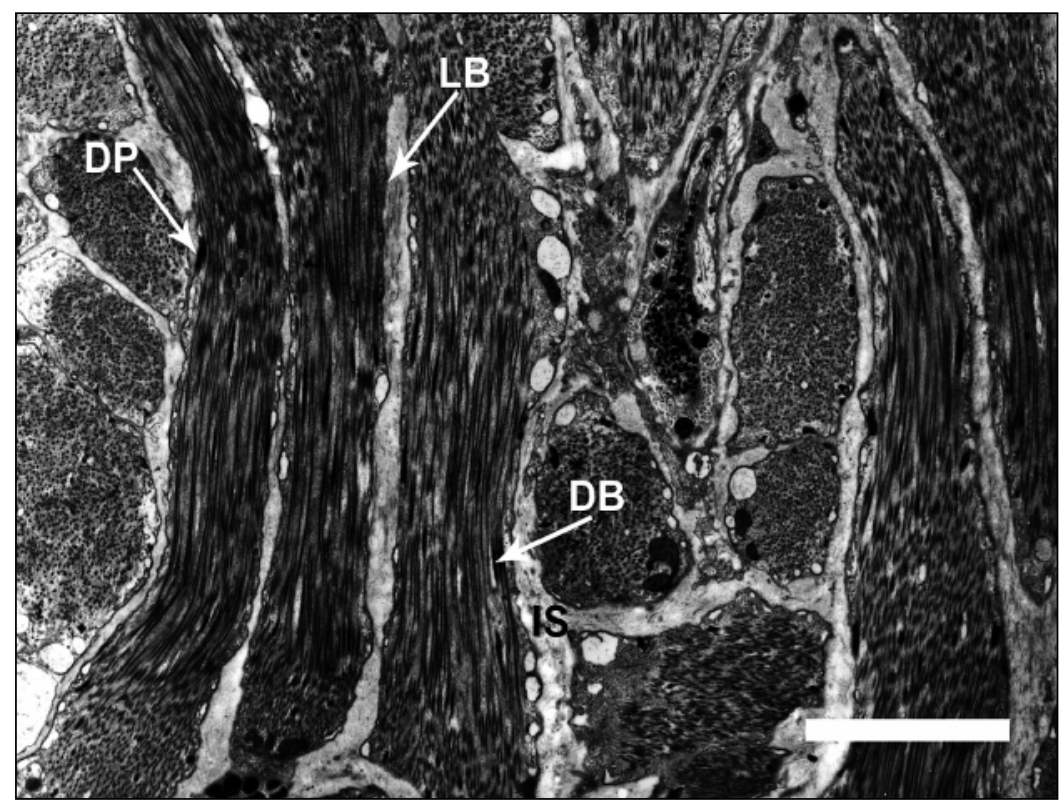

Fig. 5. Longitudinal and cross sections through smooth muscle cells in the superficial integumental layer of Helix pomatia. The cytoplasm contains thick and thin myofilaments and dense bodies (DB). Dense plaques (DP) are located on the plasma membrane. All SMC are surrounded by lamina basalis (LB). Intercellular spaces (IS) are filled with a meshwork of individual collagen fibrils. Transmission electron micrograph. Bar indicates $5 \mu \mathrm{m}$.

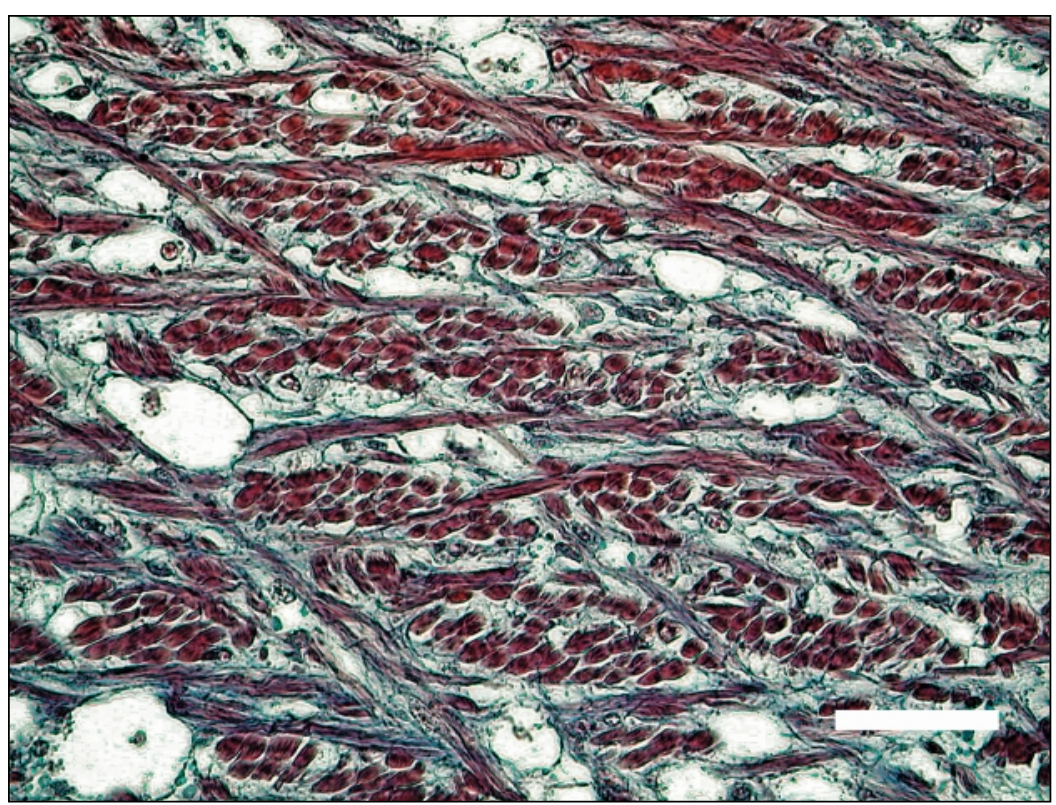

Fig. 6. Subepithelial collagenous connective tissue (blue) of Arion rufus with three-dimensional mesh of smooth muscle cell bundles (reddish) and haemocoelic sinuses (empty space). Layer Arion1, Mallory's blue trichrome. Bar indicates $50 \mu \mathrm{m}$. 